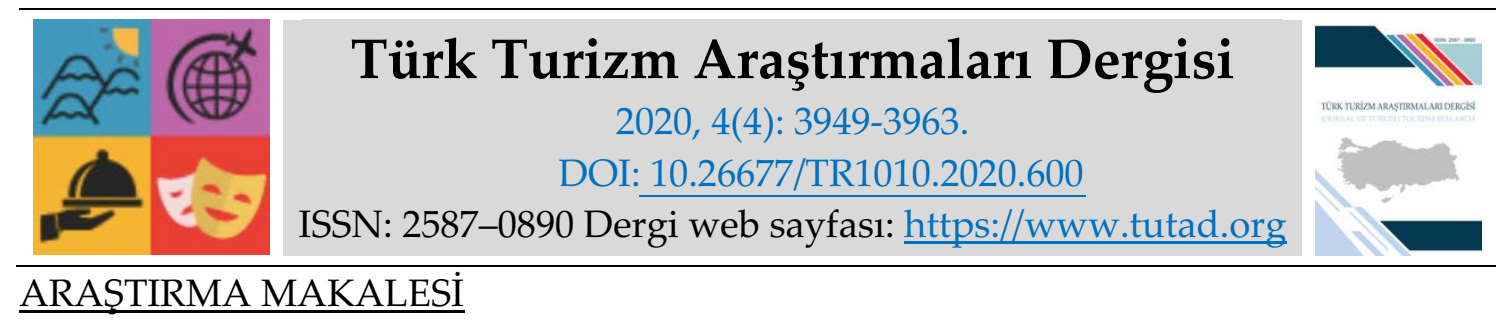

\title{
X, Y ve Z Kuşağı Tüketicilerin Kahve Dükkanlarını Tercih Etme Alışkanlıklarının İncelenmesi*
}

Öğr. Gör. Mehmet Selman BAYINDIR, Kırklareli Üniversitesi, Pınarhisar MYO, Kırklareli, eposta: mbayindir@klu.edu.tr

ORCID: https://orcid.org/0000-0002-9806-3522

Arş. Gör. Bahar BAYINDIR, Kırklareli Üniversitesi, Turizm Fakültesi, Kırklareli, e-posta: bbayindir@klu.edu.tr

ORCID: https://orcid.org/0000-0002-6440-1132

Doç. Dr. Sibel ÖNÇEL, Anadolu Üniversitesi, Turizm Fakültesi, Eskişehir, e-posta: sguler@anadolu.edu.tr

ORCID: https://orcid.org/0000-0001-9973-6058

\section{Öz}

Kamusal mekan olma özelliği taşıyan kahve dükkanları tüketicilerin farklı yönlerden elde edebileceği deneyimler sağlamaktadır. Bu çalışmanın amacı kahve dükkanlarını tercih eden $X, Y$ ve $Z$ kuşağı tüketicilerin tüketim alışkanlıklarını ortaya çıkarmaktır. Bu amaç çerçevesinde nitel araştırma yöntemlerinden görüşme tekniği kullanılarak on üç katılımcıyla yarı yapılandırılmış sorular ile görüşme gerçekleştirilmiştir. Görüşmeler sonucunda beş başlık altında bulgular toplanmıştır. Bunlar; katılımcıların, kahve dükkanlarını tercih etme alışkanlıkları, marka tercihleri, hizmet beklentileri, önem verdikleri fiziki unsurlar ve satın aldıkları ürünler olarak belirlenmiştir. Bulgular sonucunda $X$ kuşağı katılımcıların diğer kuşaklara göre daha az kahve dükkanlarına gittikleri, standardı yakalayan markaların daha çok tercih edildiği, $X$ kuşağının masaya servisi, $Z$ kuşağının self-servisi ve $Y$ kuşağının her iki servis türünü de tercih ettiği anlaşılmaktadır. $X$ kuşağı daha rahat, $Y$ kuşağı daha modern ve $Z$ kuşağı ise daha özgün ortamları tercih etmektedir. X kuşağı filtre ve Türk kahvesi gibi daha geleneksel kahveleri, Y kuşağı V60, sifon, chemex ve cold brew gibi daha yenilikçi ve modern yöntemlerle hazırlanmış kahveleri ve $Z$ kuşağı ise farklı şurup, özüt, çikolata ve kremalar ile hazırlanmış kahveleri tercih etmektedir.

* Bu makalenin bir kısmı 19-21 Eylül 2019 tarihinde IV. Uluslararası Gastronomi Turizmi Araştırmaları Kongresi bildirili kitabında "Kahve Dükkanlarını Tercih Eden X, Y ve Z Kuşağı Tüketicilerinin Tüketim Alışkanlıklarının İncelenmesi" başlı̆̆ı ile 1812 sözcük olarak yayınlanmıştır.

Anahtar Kelimeler: Kahve, Kahve Dükkanları, Kuşaklar, Tercih Etme Alışkanlıkları, İçecekler.

Makale Gönderme Tarihi: 13.07 .2020

Makale Kabul Tarihi: 09.10.2020

\section{Önerilen Atıf:}

Bayındır, M. S., Bayındır, B. ve Önçel, S. (2020). X, Y ve Z Kuşağ1 Tüketicilerin Kahve Dükkanlarını Tercih Etme Alışkanlıklarının İncelenmesi Türk Turizm Araştırmaları Dergisi, 4(4): 3949-3963.

(C) 2020 Türk Turizm Araştırmaları Dergisi. 


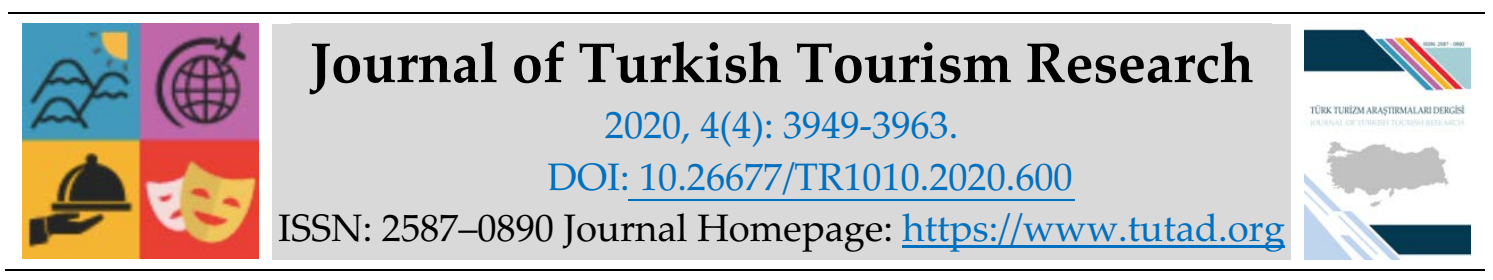

\title{
RESEARCH PAPER
}

\section{Investigation of $\mathrm{X}, \mathrm{Y}$ and $\mathrm{Z}$ Generation Consumers Habits of Choosing Coffee Shops}

Lecturer Mehmet Selman BAYINDIR, Kırklareli University, Pınarhisar Vocational School, Kırklareli, e-mail: mbayindir@klu.edu.tr ORCID: https://orcid.org/0000-0002-9806-3522

Research Assistant Bahar BAYINDIR, Kırklareli University, Faculty of Tourism, Kırklareli, email: bbayindir@klu.edu.tr

ORCID: https://orcid.org/0000-0002-6440-1132

Associate Prof. Dr. Sibel ÖNÇEL, Anadolu University, Faculty of Tourism, Eskişehir, e-mail: sguler@anadolu.edu.tr

ORCID: https://orcid.org/0000-0001-9973-6058

\begin{abstract}
Coffee shops, which are public spaces, provide experiences that consumers can provide in different ways. The purpose of this study is to reveal the consumption habits of consumers, who prefer $\mathrm{X}, \mathrm{Y}$, and $\mathrm{Z}$ generation, who prefer coffee shops. For this purpose, interviews were conducted with thirteen participants with semi-structured questions using the interview technique, which is one of the qualitative research methods. As a result of the interviews, findings were collected under five headings. These; The habits of the participants to choose coffee shops, brand preferences, service expectations, the physical elements they care about and the products they buy are determined. As a result of the findings, it is understood that the participants of the $X$ generation go to less coffee shops than the other generations, the brands that meet the standard are more preferred, the $X$ generation service to the table, the $Z$ generation self-service and the $Y$ generation prefer both service types. Generation $X$ is more comfortable, Generation $Y$ is more modern and Generation $\mathrm{Z}$ prefers more original environments. They prefer more traditional coffees such as $\mathrm{X}$ belt filter and Turkish coffee, coffees prepared with more innovative and modern methods such as $Y$ generation V60, siphon, chemex and cold brew, and Z generation coffees prepared with different syrups, extracts, chocolates and creams.
\end{abstract}

Keywords: Coffee, Coffee Shops, Generations, Preferring Habits, Drinks.

Received: 13.07 .2020

Accepted: 09.10.2020

Suggested Citation:

Bayındır, M. S., Bayındır, B. and Önçel, S. (2020). Investigation of X, Y and Z Generation Consumers Habits of Choosing Coffee Shops, Journal of Turkish Tourism Research, 4(4): 3949-3963.

(C) 2020 Türk Turizm Araştırmaları Dergisi. 


\section{GİRIŞ}

Günümüzde kentlerdeki yaşam hızı geçmişe göre daha hızlı bir şekilde devam etmektedir. Ev ve iş yeri arasında gidip gelen insanlar; sosyal gereksinimlerini karşılamak, rahatlatıcı ve çok sayıda etkileşim kurabileceği üçüncü mekânlara ihtiyaç duymaktadır (Oldenburg, 1989). Modern toplum içerisinde bir yaşam tarzı haline gelen kahve dükkanları (Sangian vd., 2020) yalnızca tüketim alanı olarak değil aynı zamanda insanların sosyalleşmesini sağlayan ve onları sosyal ortamlara teşvik eden önemli üçüncü mekanlardan biri olmaktadır (Huang, 2017; Manzo, 2014). Kahve dükkanlarını tercih eden insanlar; sunulan ürün ve hizmetten faydalanmak, akranları ve aileleri ile sosyalleşmek veya kişisel deneyim yaşamak gibi farklı yönlerden edinebileceği birçok deneyim elde etmektedir (Grinshpun, 2014; Huang, 2017).

Son yıllarda kahve dükkanlarının sayısı büyük ölçüde artış göstererek özellikle genç kuşağın kahve tüketimine ve kahve dükkanlarına olan ilgisinin artmaktadır (Wei vd., 2019). Lüks restoran veya kahve dükkanlarını kendini ifade etme ve arzu ettikleri yaşam tarzının bir sembolü olarak gören genç tüketiciler, (Phau ve Cheong, 2009) aynı zamanda kahve dükkanlarında kahve içme alışkanlığını modaya uygun olarak görmektedirler (Danziger, 2005). Özellikle son yıllarda Türkiye'de de genç kuşağın batı kültürünün de etkisiyle birlikte kahve tüketimine ve kahve dükkanlarına olan ilgisinin arttığı söylenebilmektedir.

Kahve dükkanları özellikle genç kuşak tarafından tercih edilen dikkat çekici mekanlar olmasına karşın, Aşık (2017) kahve dükkanlarında kahve tüketiminin; tüketicilerin cinsiyet, meslek, gelir düzeyi gibi bazı değişkenlere göre farklılık gösterebileceğini belirtmektedir. Tüketicilerin satın alım kararlarında etkili olan en önemli demografik özelliklerden biri de yaş faktörüdür (Kotler, 2000). Brewer (2015) her kahve ve kahve dükkanının farklı kuşaklara hitap ettiğini belirtmektedir. Her kuşağın kendine has beklenti, deneyim, yaşanmışlığı, yaşam tarzı, değerleri bulunmaktadır ve tüm bu etkenler tüketicilerin satın alma kararında önemli bir etken olmaktadır (Sarıtaş ve Süleyman, 2016). Bu açıdan incelendiğinde, kahve dükkanlarında yaşanan deneyiminde tüketiciler arasında kuşaklara göre bir farklılık olabileceği düşünülmektedir.

Kahvenin ve kahve dükkanlarının popülaritesinin ve öneminin artması nedeniyle kahve ve kahve dükkanlarına yönelik tüketim alışkanlıklarını ortaya çıkarmak amacıyla birçok çalışma yapılmıştır (Aşık, 2017; Samoggia ve Riedel, 2018). Bu çalışma ile kahve dükkanlarını tercih eden $X, Y$ ve $Z$ kuşağı tüketicilerinin tüketim alışkanlıkları ortaya çıkarılmaya çalışılmıştır. Aynı zamanda bu çalışma ile kahve dükkanlarını tercih eden hedef kitleyi ve tüketicileri kuşaklara göre en doğru şekilde analiz etmek ve anlamak istenmektedir.

\section{KAVRAMSAL ÇERÇEVE}

Kahve dükkanları (kafe, kahvehane ve kahve barı olarak da adlandırılmaktadır.) kahve olmak üzere birçok içecek çeşidinin ve yiyeceğin satıldığı, hazırlandığı, servis edildiği ve tüketildiği mekanlar olarak belirtilmektedir. Kahve dükkanları yalnızca bir tüketim alanı değil aynı zamanda insanların etkileşime girmesine yardımcı olan sosyal ve keyifli mekanlar olarak tanımlanmaktadır (Chadios, 2005; Manzo, 2014).

Son yıllarda birçok ülkede popüler hale gelen kahve dükkanları (Schmidt vd., 2012), Türkiye'de de insanların günlük yaşamının bir parçası olarak şehir merkezlerinde önemli bir rol oynamaktadır. Hem yerli hem de yabancı kahve dükkanlarının Türkiye pazarında tek tek yer almasıyla birlikte bu mekanlar tüketicilerin sosyal yaşamına önemli derecede katkı sağlamıştır (İnce, 2018). 
Her yaştan ve farklı statüden tüketici profiline sahip olan kahve dükkanları, özellikle genç kuşak tarafından sıklıkla tercih edilmektedir. Kim (2016) kahve dükkanlarını tercih eden tüketicilerin yaşının kahve dükkanı tercihini etkilediğini belirtmektedir. Yaş, tüketicilerin satın alma kararlarını etkileyen en önemli faktörlerden biri olmaktadır (Kotler, 2000). Tüketicilerde yaşanan kuşak farklılıkları tüketicilerin deneyimlerini, yaşam biçimlerini, değerlerini ve satın alma davranışlarını etkilemektedir (Williams ve Page, 2011). Bu sebeple marka ve firmalar, rekabet ortamında ayakta kalabilmek için her kuşağın kendine ait tüketim alışkanlıklarını iyi bilmelidir.

Türk Dil Kurumu Felsefe Terimleri Sözlüğü' nün belirtmiş olduğu tanımına göre kuşak kavramı; yaklaşık olarak benzer yıllarda doğmuş, aynı çağın koşullarını sahip olan, dolayısıyla birbirine benzer olay, sıkıntıları yaşamış ve benzer ödevlerle yükümlü olmuş kişiler topluluğudur (Albayrak ve Özkul, 2013; Bezgin, 2016; Gümüş, 2020). Farklı bir tanımlama ile kuşak, genellikle aynı zaman aralığında doğup büyümüş ve yaşam şekilleri birbirlerine benzeyen bireylerin oluşturduğu toplulukları tanımlamakta kullanılmaktadır (Strauss ve Howe, 1991). Bu tanımlardan hareketle aynı kuşakta bulunan kişiler birbirine yakın tarihlerde doğdukları için kişilerin tutumu, davranışları ve benzer olaylara vermiş oldukları tepkiler aynı olabilmektedir (Aydın ve Başol, 2014).

Her kuşağın kendine özgü özellikleri, değerleri, tutumları, güçlü ve zayıf tarafları bulunmaktadır (Lower, 2008). Bu özellikler kuşaklar arasındaki ayrımların ortaya çıkmasına neden olmaktadır (Ünver, 2019). Literatür incelemesi sonucunda kuşaklar arasındaki ayrım için belirtilen tarih aralıklarıyla ilgili kesin bir bilgi birliği olmadığı görülmüştür. Twenge vd., (2010) günümüzde beş kuşağın bireylerinin bulunduğunu ifade ederek bu kuşakları: Sessiz Kuşak, Bebek Patlaması (Baby Boomers), X Kuşağı, Y kuşağı ve Z Kuşağı şeklinde belirtmektedir. Çalışma amacı doğrultusunda incelenen $X, Y$ ve $Z$ kuşağının tarih aralığı literatür sonunda şu şekilde belirtilmektedir: X kuşağ1 için genellikle 1965-1980 ve Y kuşağı için genellikle 1981-1999 tarih aralığında doğan bireyler iken Z kuşağı 2000 yılından sonra doğan bireyler için kullanılmaktadır (Başgöze ve Bayar, 2015, Lancester ve Stillman, 2002, Trower, 2009).

1965-1980 yılları arasında dünyaya gelen bireylerden oluşan X kuşağı, ekonomik zorluklarla dolu bir döneme denk geldiği için "Kayıp Kuşak" olarak adlandırılmaktadır (Bayraktaroğlu ve Özbek, 2018). Yaşamış oldukları gelecek kaygısı; bireyleri daha çok çalışmaya, kariyer yapmaya ve daha fazla para kazanmaya odaklamıştır (Altuntuğ, 2012). Ayrıca bu kuşakta bulunan bireyler, toplumsal sorunlara karşı duyarlı, kanaatkar idealist ve sadık bireylerdir (Başgöze ve Bayar, 2015). Eğitim seviyelerinin yüksek olması bir tüketici olarak satın alma davranışlarını da büyük ölçüde etkilemektedir. Gülez (2014) tarafından gerçekleştirilen çalışmada bu kuşağın bireylerinin zamanlarının büyük bir kısmını ev ve işyerleri dışında üçüncü mekanlarda geçirdiklerini belirtmektedir. Aynı zamanda bu kuşak alışveriş merkezleri ile karşılaşan bireyler olmaları nedeniyle kazandıkları parayı ürün ve hizmet satın alarak değerlendirmektedirler.

Sorgulayan yapıları nedeniyle "Why" kuşağı olarak da adlandırılan (Kuru, 2014) Y kuşağı, 19811999 yılları arasında dünyaya gelen bireylerden oluşmaktadır (Başgöze ve Bayar, 2015). Bu kuşaktaki bireyler, enformasyon ve bilginin yoğun olduğu bir dönemde dünyaya geldikleri için girişimci ruha sahip ve kendilerine güvenen bireyler olmakla birlikte aynı zamanda sabırsız bireyler olarak da bilinmektedirler (İzmiroğlu, 2008). Y kuşağı tüketicileri; yeniliğe açık, hayattan zevk almayı seven, alışveriş yapmaktan keyif alan ve para harcamayı çok seven bireyler olarak tanımlanmaktadır (Parker vd., 2004).

İnternet kuşağı, kristal kuşak, .com kuşağı ve Google kuşağı olarak da tanımlanan Z kuşağı, teknoloji ile doğan ve teknolojinin ilerlemesine tanıklık eden kuşak oldukları için teknolojik aletleri çok iyi kullanmaktadırlar (Berkup, 2014; Çetin ve Karalar, 2016; Levickaité, 2010). Ancak bu kuşaktakiler sosyal medyayı diğer kuşakların aksine ürün ve hizmetler hakkında bilgi 
edinmek, fiyat karşılaştırması yapmak ve iş birliği yapma gibi konularda etkili bir şekilde kullanmaktadırlar (Sarığlu ve Özgen, 2018). Z kuşağının sosyal medyayı bu derece etkili bir şekilde kullanmaları nedeniyle aileleri içinde tüketim kararlarında etkili olabilmektedirler. Bu sebeple Z kuşağı pazarlamacıların çok fazla önem verdiği bir kuşaktır (Altuntuğ, 2012; Gümüş, 2020). Ayrıca bu kuşak; yeniliğe açık, gelenekselden ziyade yeni yollarla merakını tatmin etme alışkanlığına sahiptir (Tuncer ve Tuncer, 2016).

Her kuşakta ortaya çıkan değişik olgu ve olaylar kuşakların farklı yaşam tarzının oluşmasına ve farklı tercihler yapmalarına sebep olmaktadır (Danışman ve Gündüz, 2018). Bu nedenle bireylerin yaşları tüketici davranışlarını önemli bir şekilde etkilemektedir (Ilgaz, 2018). Literatür incelendiğinde $X, Y$ ve $Z$ kuşağının farklı özelliklere sahip olduğu bundan dolayı da tüketim davranışlarına farklı şekillerde yansıdığı anlaşılmaktadır. Bu nedenle yapılmış ya da yapılacak olan çalışmalarda bu faktörlerin göz önünde bulundurulması gereklidir. Bireylerin tüketim davranışlarını anlamak ve çeşitli çıkarımlarda bulunmak için bireyleri ait oldukları kuşaklara göre değerlendirmek gerekmektedir. Bu çalışma ile kahve dükkanlarını tercih eden tüketicilerin tercih etme alışkanlıkları bireylerin ait oldukları kuşağa göre incelenmektir.

\section{YÖNTEM}

$\mathrm{Bu}$ çalışma kahve dükkanlarını tercih eden $\mathrm{X}, \mathrm{Y}$ ve $\mathrm{Z}$ kuşağı tüketicilerinin tercih etme alışkanlıklarının incelenmesini amaçlamaktadır. Bu doğrultuda çalışmanın evrenini Antalya il merkezinde yaşayan ve daha önce kahve dükkanlarında yiyecek-içecek vb. gida ürünlerini tüketen tüketiciler oluşturmaktadır. Nitel araştırma yöntemi benimsenen çalışmalarda örneklem büyüklügü araştırma konusuna, araştırma odağına, elde edilen veri miktarına ve örnekleme türüne göre farklılık gösterebilmektedir (Ylldırım ve Şimşek, 2018). Creswell (2018), nitel araştırma yöntemlerinde örneklem sayısının araştırma konusu ve araştırma odağı gibi unsurlar doğrultusunda 1 ile sinırlı tutulabileceğini, ancak 300 ve daha üzerinde sayıla da gerçekleştirilebileceğini belirtmiştir. Bu araştırmada katılımcıların ve araştırma sahasının araştırma amacına uygun seçilmesi ve katılımcıların araştırmaya istekli katılımının sağlanması için amaçlı örnekleme türü tercih edilmiştir. Araştırma örneklemini ise her bir kuşaktan 5'er katılımcı olacak şekilde toplam 15 katılımcı oluşturmaktadır.

Araştırma, $X, Y$ ve $Z$ kuşağından tüketicilerle nitel araştırma yöntemlerine uygun şekilde hazırlanmış yarı yapılandırılmış sorularla derinlemesine görüşmeler yapılarak gerçekleştirilmek istenmiştir. Bu bağlamda katılımcıların kahve dükkanlarını tercih etme alışkanlıklarının ortaya çıkarılması amaçlamaktadır. Araştırmanın amacı doğrultusunda, kahve dükkanlarında, yemeiçme deneyimine sahip katılımcılarla görüşme yapılması tercih edilmiştir.

Araştırma için 2019 yılı Temmuz ayı içerisinde 15 katılımcı ile görüşme takvimi oluşturulmuştur. Ancak iki katılımcı sonradan görüşme gerçekleştiremeyeceğini belirtmiştir. Toplam 13 katılımcıyla araştırma verileri toplanmıştır. Görüşme takvimi araştırmaya katılan katılımcılara uygun zamanda ulaşabilmek ve görüşmenin daha verimli geçmesi amacıyla hazırlanmıştır. Görüşmeler sırasında sorulacak sorular önceden hazırlanmış ancak görüşmenin akışına bağlı olarak daha detaylı bilgi elde edilebilmesi amacıyla yarı yapılandırılmış sorularla görüşme tekniği tercih edilmiştir. Görüşme takvimi doğrultusunda görüşmelerin daha verimli olacağ 1 düşünülerek katılımcıların tercih ettikleri kahve dükkanlarında görüşmeler gerçekleştirilmiştir. Ayrıca çalışmanın değerlendirmesi görüşme yapılan katılımcılarla sınırlı kalmaktadır. 


\section{BULGULAR}

Katılımclarının demografik özelliklerine ilişkin bilgiler Tablo 1'de belirtilmiştir. Araştırmaya katılan katılımcllara K1, K2, K3, K4, K5, K6, K7, K8, K9, K10, K11, K12 ve K13 olmak üzere katılımcı kodları tanımlanmıştır. Tablo incelendiğinde 13 katılımcıdan beşinin $\mathrm{Y}$ kuşağı, dördünün $X$ kuşağı ve kalan dördünün de $Z$ kuşağı olduğu görülmektedir. $Z$ kuşağ1 katılımcıların üçü öğrenci ve biri çalışandır. Y kuşağı katılımcıların tamamı çalışandır. Yaş dağılımlarına bakıldığında tüm katılımcıların kendi kuşaklarının yaş aralığındaki yaşta oldukları görülmektedir.

Tablo 1. Katılımcıların Demografik Özelliklerine İlişkin Bilgiler

\begin{tabular}{ccccl}
\hline Katılımcılar & Cinsiyet & Yaş & Kuşak & \\
\hline K1 & Erkek & 52 & X & Devlet Memuru \\
K2 & Erkek & 44 & X & Turizm (İşletme Müdürü) \\
K3 & Kadın & 41 & X & Akademisyen \\
K4 & Kadın & 47 & X & Çalışmıyor \\
K5 & Kadın & 32 & Y & Hemşire \\
K6 & Kadın & 26 & Y & Öğrenci \\
K7 & Erkek & 29 & Y & Akademisyen \\
K8 & Erkek & 35 & Y & Aşçı \\
K9 & Kadın & 31 & Y & Banka Memuru \\
K10 & Erkek & 18 & Z & Öğrenci \\
K11 & Erkek & 19 & Z & Giyim Mağazası Çalışanı (Tezgahtar) \\
K12 & Kadın & 18 & Z & Öğrenci \\
K13 & Kadın & 19 & Z & Öğrenci \\
\hline
\end{tabular}

Katılımcılarla gerçekleştirilen görüşmeler neticesinde elde edilen verilerden konunun amacına uygun öne çıkan bulgular başlıklar halinde belirtilmiştir.

\section{Katılımcıların Kahve Dükkanlarını Tercih Etme Alışkanlıklarına İlişkin Bulgular}

$\mathrm{Bu}$ başlık altında katılımcıların kahve dükkanlarını tercih etmelerindeki nedenlere ilişkin bulgular yer almaktadır. Bulgular doğrultusunda X kuşağı katılımcıların aileye, aile bağlarına ve aile fikirlerine daha fazla önem verdikleri için genellikle kahve dükkanlarına aileleriyle birlikte vakit geçirmek için gittikleri düşünülmektedir. Y kuşağı katılımcıların kendi yaş grubundan kişilerle vakit geçirmek ve yoğun çalışma temposundan uzaklaşmak için kahve dükkanlarına gittikleri anlaşılmaktadır. Z kuşağı katılımcıların ise kahve dükkanlarına arkadaşlarıyla birlikte gittikleri, özellikle sosyal medyanın kahve dükkanlarına gitmelerinde bir etken olduğu, yine sosyal medyada yapacakları fotoğraf vb. görsel öğeler yüklemelerinin ve konum paylaşmalarının da kahve dükkanlarına gitme sebepleri arasında olduğu söylenebilir. Aynı zamanda Z kuşağı katılımcların farklı kahveleri deneyimlemeye açık oldukları ifade edilebilir.

$X$ kuşağı katılımcıların kahve dükkanlarına $Y$ ve $Z$ kuşağı katılımcılara göre daha az gittikleri anlaşılmaktadır. Y kuşağı katılımcıların iş aralarında ya da hafta sonu tatillerinde kahve dükkanlarına gittikleri söylenebilir. Z kuşağı katılımcıların ise kahve dükkanlarına daha sık gittikleri anlaşılmaktadır.

Eşimle birlikte dışarı çıktığımda beraber bir şeyler içmek istediğimizde kahve dükkanlarını tercih ediyoruz. Kahve dükkanları hem fiyat olarak hem de eşimle birlikte AVM ya da bir cadde üzerinde oturup bir şeyler 
içeceğimiz kışın sıcak yazın ise serin oluyor (K1). Kahve dükkanlarına dışarıya çıktığımızda yemek sonrası kahve içmeyi sevdiğimiz için gidiyoruz Genellikle eşimle ya da iş yerinden idareci diğer arkadaşlarımla birlikte gidiyoruz (K2). Kahve içmeyi seviyorum, işim gereği bazen, internet bağlantısı bulunan bir kahve dükkanına işlerimi ve çalışmalarımı yapmak için de gidiyorum. Okuldan hoca arkadaşlarımla gittiğim gibi eşimle de gidiyorum (K3). Ben eşimle ya da komşumla birlikte gidiyorum. Genellikle sohbet etmek için kahve dükkanlarma gidiyoruz (K4).

Yoğun iş temposunda gün içerisinde dinlenebilmek için kahve dükkanlarnna giderim (K9). İş arkadaşlarımla sohbet etmek için öğle arası veya iş çıkışı kahve dükkanlarına giderim (K7). İş arkadaşlarımla, ya da eşim ve çocuklarımla birlikte kahve dükkanlarına gideriz. Çocuklar kahve içmiyor ama onlar için de meyve suyu, limonata gibi içecekler ya da pasta tarzı yiyecekler alıyoruz (K5). İşimin yoğun olması ve yalnızca haftada bir gün iznimin olması sebebiyle ailem ve arkadaşlarımla dışarıya çıktı̆̆ımızda genellikle kahve dükkanların tercih ederiz. Kahve dükkanları sevdiğim insanlarla vakit geçirmem için birçok imkan sunuyor. Aynı zamanda evde yapılması zor olan kahveleri zaman kaybı olmaması için genellikle kahve dükkanlarında gelip içmeyi tercih ederiz (K8). Ben yüksek lisans öğrencisiyim, kahve dükkanlarına kütüphanede çalışmaktan sıkılınca geliyorum. Burada da yine çalışmalarımı yapıyorum, kahve içiyorum, kahvenin bana iyi geldiğini düşünüyorum. Genellikle bu dönemde tek başıma geliyorum ama normalde arkadaşlarımla birlikte gelmeyi tercih ediyorum (K6).

Genellikle arkadaşlarımla gidiyorum. Kahve dükkanlarına arkadaşlarımla vakit geçirmek için gidiyorum. Güzel sohbet ortamı oluyor. Haftada en az bir kez gidiyoruz (K10). Kahveyi çok sevmesem de arkadaşlarmmla birlikte kahve dükkanlarma gidiyorum. Bazen ailemle de gidiyorum (K11). Genellikle arkadaşlarımla birlikte haftada iki üç kez gidiyoruz. Yazın neredeyse her gün arkadaşlarımla gidiyorum, bazen fotoğraf çekmek için bile gittiğimiz oluyor (K12). Farklı kahveleri denemeyi seviyorum. Yazın ya da kışın kahve dükkanlarına gitmeyi seviyorum (K13).

\section{Katılımcıların Kahve Dükkanları Marka Tercihine İlişkin Bulgular}

Katılımcıların kahve dükkanları marka tercihleri incelendiğinde çoğunluğun tanınmış markaları tercih ettiği söylenebilir. Bu tercihlerinde en önemli iki unsur öne çlkmaktadır. Bunlardan biri standart lezzetin korunması bir diğeri ise birçok kişi tarafından da tercih ediliyor olmasıdır. Bununla birlikte farklı lezzetlerin ve yeni mekanların deneyimlenmesi amacıyla katılımcıların bir kısmının marka tercihlerinde değişikliğe gittikleri ifade edilebilir. Özellikle $Z$ kuşağı katılımcıların sosyal medya kullanıma bağlı olarak zincir işletmeleri tercih ettiği gibi butik kahve dükkanlarını da tercih ettikleri düşünülmektedir.

X kuşağı katılımcların genellikle yerli kahve dükkanlarını, Y kuşağı katılımcıların yerli ya da yabancı olmasından daha çok standardın yakalandığı işletmeleri ve $Z$ kuşağı katılımcıların ise özgün ve ünlü kahve dükkanlarını tercih ettikleri anlaşılmaktadır.

Benim için marka çok fark etmiyor. Bazen yorulduğumuz yerde dinlenmek için bir giriyoruz arkadaşlarla. Ama tercih edecek olursam yerli markaları tercih ediyorum (K1). Farkl markalar ve yeni açlan yerler olursa buralar deniyorum. Onun haricinde tanınmış markaları tercih ediyorum. Bu markalar standartlarını korudukları için kahvemi içerken kahvenin kötü tadı, demlemenin yanlış yapılması gibi olumsuz durumlarla karşılaşmıyorum (K2). Birkaç tanınmış marka dışında başka yerleri tercih etmiyorum. Bu markalarn kahvelerinin ve hizmetlerinin iyi olduğunu düşünüyorum. Misafirlerim gelirse onlarla da bu her zaman gittiğim yerleri gitmeyi tercih ediyorum (K3). Arkadaşlarla bazen dışarıya çıktı̆̆ımızda genellikle soğuk bir şeyler içmek için gidiyoruz. Tadı güzel olduktan sonra marka çok tanındık olmasa da olur (K4).

Tanınmış markalar olmasına çok dikkat etmesem de tercih yaptığım zamanlarda bildiğim ve tanınan bir yeri tercih ediyorum (K5). Butik mekanları tercih ediyorum. Kendilerine özgü sunum ya da içecekleri 
olması bana çekici geliyor (K6). Yerli markaları tercih ediyorum. Bu markalarda dikkat ettiklerim ürün çeşitliliği ve standardı korumalar oluyor. Bazen çok ürün gördü̆̆̈̈müz menülerde, ürünler için çok güzel diyemiyoruz (K7). Genellikle yerli markalara gidiyorum. Yeni açlmış yerleri de deniyorum (K8). Yabancı markalara gitmeyi tercih ediyorum. Kahvenin tadının buralarda daha güzel olduğunu düşünüyorum (K9).

Genellikle tanınmış yerleri tercih ediyorum. Bir de bunun dışında sosyal medyada öne çıkan yerlere gitmeye çalışıyorum (K10). Bilindik markalara gidiyorum. Farklı yerlerde bazen güzel kahve yapmıyorlar (K11). Genellikle kendine özgü teması olan, standart yerlerden farklı olan kahve dükkanlarına gidiyorum. (K12). Sosyal medyada fotoğraf ya da yer paylaşımı yaptığımda birçok kişinin görebileceği veya birçok kişi tarafindan tercih edilen yerlere gidiyorum (K13).

\section{Katılımcıların Kahve Dükkanlarında Hizmet Beklentilerine İlişkin Bulgular}

Katılımcıların hizmet beklentilerine bakıldığında X kuşağı katılımcılar için masadan sipariş alınması ve siparişlerinin masaya getirilmesini, porselen ya da camdan imal edilmiş ürünlerle içecek ya da yiyeceklerinin sunulmasını, çalışanların giyiminin iyi olması ve siparişlerin yanında ikramlıklar verilmesinin önemli olduğu görülmektedir. Y kuşağı katılımcıların da X kuşağı katılımcllarına benzer şekilde masaya servis yöntemini ve porselen ya da camdan imal edilmiş ürünlerle sunumu tercih ettikleri söylenebilir. Ancak çalışan ya da kahve içmek için sınırlı zamana sahip olan katılımcıların karton bardak da ve self servis yöntemini de tercih ettikleri anlaşılmaktadır. İşletmede aldıkları ürünün yanında ikramlık olmasının önemli olduğu ifade edilebilir. Y kuşağı katılımcıların, kişisel hijyenini sağlayan, iletişimi kuvvetli, çalışırken iş giysisi (üniforma) giyen çalışanlardan hizmet almak istedikleri anlaşılmaktadır.

Z kuşağı katılımcıların karton bardakta self servisi tercih ettikleri söylenebilir. Bu durumun dışında bazen arkadaşlarıyla kahve dükkanına gittiklerinde, toplu sipariş verilirken, siparişlerin masaya servis edilmesinin tercih edildiği görülmektedir. Çalışanların kendi yaşına yakın yaşlarda olmaları ve çalışanların giyimlerinin rahat olmasını istedikleri anlaşılmaktadır. Gittikleri kahve dükkanlarında ücretsiz internet erişimi, cep telefonları için şarj aleti ve oturdukları masa çevresinde piriz olmasının önemli olduğu ifade edilebilir. Ayrıca çalışanların resmi davranışlarından daha çok arkadaşça davranmalarının Z kuşağı katılımcılar için önemli olduğu söylenebilir.

Masaya oturduğumda birilerinin gelip sipariş almasını ve getirmesini isterim. Kahvemi porselen fincanda içmek isterim. Başka bir içecek söylediysem yine porselen ya da camda olması benim için önemli. Karton bardak gibi şeylerde bir şeyler içmek ya da yemek hoşuma gitmiyor. Bir de kahve ya da çayla birlikte ücretsiz mini kurabiye veren yerler var bu bence işletmenin bana önem verdiğini gösterir (K1). Gittiğimde benden sipariş alan birinin olmasın tercih ederim. Ancak günümüzde self-servis gibi yöntemlere de sıklikla rastlanmakta. Farklı temalarda farkl hizmet şekillerine rastlasam da bir tercihim olursa bu masaya gelinip sipariş alınması yönünde olur. Siparişimde porselen fincan kullanılmasını isterim (K2). Genellikle masadan sipariş alınan yerleri tercih ederim. Kartondan üretilmiş bardak vb. sipariş getirilmesi bana hitap etmiyor. Bu durum aslında bende işletme için, tarafindan kolaya kaçılıyormuş, içeceğini al ve git der gibi bir imaj oluşturuyor (K3). Siparişimin masada alınmasım ve porselen fincanda ya da cam bardakta getirilmesini tercih ederim. Satın aldıklarımın yanında küçük kurabiye ya da çikolata gibi ücretsiz ürünlerden bir tane de olsa getirilmesi beni memnun eder. Çalışanların tertipli ve düzenli çalışması, giyiminin düzgün olması da önemlidir (K4).

Servis şekli çok fark etmiyor genelde kullanılan ürünlerin temizliğine bakıyorum. Bazı yerlere gittiğimde porselen fincanların çok temiz olmadığı görüyorum ve karton bardaklarm porselen fincanlardan daha hijyenik olduğunu düşünüyorum. Bir de işletmenin mevsimlere özel ürünleri, örneğin yazın soğuk içecek, kışın sıcak içecek çeşidini artırması da güzel bir uygulama oluyor (K5). Self servisi tercih hizmet bana daha 
cazip geliyor. Kahvemi içmeye dışarıda devam etmek istediğimde elimde taşıyabiliyorum (K6). Masadan sipariş alınması ve sipariş sonrası bir isteğim vb. olduğunda ulaşabileceğim bir servis elemanın olmasını isterim. Kahve içerken eksik vb. durumda tekrar kalkıp masaya geri oturmak bana göre değil (K7). Bir restorana ya da kafeye gittiğimde benden sipariş alınmasını isterim. Sonuçta ben oraya gitmek için vakit ayırıyorum. Öğrenci kantini ya da fast food işletmeler gibi hem sipariş de hem ödeme de hem de istediğim içeceği alırken sıra beklemek istemem. Bunun dışında güler yüzlü olunması, çalışanların üniformalarmın olması, bu üniformalarda çalışanların isimlerinin yazması ve ütülü düzgün olmasını beklerim (K8). Siparişimi o anki duruma göre masada alınmasın ya da acelem varsa self servis olmasinı tercih ederim. Siparişimi masada verdiysem yanında ufak ikramlar olması güzel olur. Çalışanların nazik konuşması, konuşurken bana bakması ve ter kokmaması benim için çok önemlidir (K9).

Benim için mekanın imajı önemli. Self servis olup çok kaliteli içecek yapan yerler olduğu gibi, menüden masada isteyip masaya gelen ama çok kalitesiz içecek yapan yerler de var. Çalışanların bana yakın yaşlarda olmasın, giyiminin ve tavirlarmin rahat olması beklerim. Ücretsiz wi-fi gibi hizmet sunan yerler var buraların internetini güvensiz bulsam da bazen kullanıyorum. Kahvemi çok hızl içeyim hemen bitsin diye düşünmem. O yüzden bazen karton bardakta kapağıyla kapatılmış olarak istiyorum. Sokakta gezerken de içebiliyorum (K10). Çalı̧anların arkadaşça davranmasın isterim bu o yeri tercih etmemde bir sebep olabiliyor. Gittiğim yerde çok kasılmak istemem doğrusu. Sipariş verirken self servis de olabilir, masadan da sipariş alınabilir bununla ilgili kesin bir tercihim yok yeter ki içtiğim kahveden tat ve zevk alayım. Bir diğer durum ise mekanda piriz ya da şarj aleti bulunması çok önemli (K11). Genelde karton bardakta ve self servis yerleri tercih ediyorum. Gezerken de kahvemi içmeye devam ediyorum. Gittiğim yer de wi-fi olursa iyi olur. Bir de piriz olması iyi oluyor. Bazen de ders çalışırken özellikle kahve dükkanlarına gidiyorum. Masa yanında piriz ve wi-fi varsa tam istediğim ortam sağlanmış demektir (K12). Arkadaşlarımla birlikte gittiğim için bazen kahvemizi alıp başka bir yere gezmek için gidiyoruz bazen de aldı̆̆ımız yerde içiyoruz. Aldı̆̆ımız yerde içersek masadan servis alınmasını tercih ediyoruz. Ama gezeceksek karton bardaklarla almak istiyoruz (K13).

\section{Katılımcıların Kahve Dükkanlarında Önem Verdikleri Fiziki Unsurlara İlişkin Bulgular}

Katılımclar için önemli olan fiziki unsurlara ilişkin bulgulara bakıldığında; $X$ kuşağ katılımcıların rahat sandalyeler, nispeten daha geniş masalar, geniş masa aralıkları gibi fiziki unsulara önem verdikleri görülmektedir. Aynı zamanda X kuşağı katılımcıların, ortamın iyi havalandırılmış olmasına, ortam ısısının iyi ayarlanmış olmasına ve gidilen yerde çok yüksek sesli müzik olmamasına önem verdikleri anlaşılmaktadır.

Y kuşağı katılımcıların önem verdikleri fiziki unsurların başında masa ve sandalyelerin rahatsız edici olmaması ve yüksekliklerinin iyi ayarlanmış olması yer almaktadır. Modern tarzda dekorların ve ekipmanların bulunması da Y kuşağı katılımcıların önem verdikleri fiziki unsurlar arasında yer almaktadır. $\mathrm{X}$ kuşağı katılımcıların tercihlerine benzer şekilde havalandırma için gerekli ekipmanların bulunmasını ve havalandırmanın iyi yapılmış olmasını istemektedirler. $Y$ kuşağı katılımcıların gidilen kahve dükkanında sigara içmek için ayrılmış bir alan ve bu alanda, yazın soğutucu, kışın ise ısıtıcıların bulunmasını ve bu alana da servis yapılmasını istedikleri anlaşılmaktadır. Aynı zamanda gittikleri kahve dükkanında tuvalet yanında olmayan, güneşin direkt olarak vurmadığı ancak aydınlık olan bir yeri tercih ettikleri söylenebilir.

Z kuşağı katılımcıların standart masa ve sandalyelerden daha çok farklı şekil ve sıradan olmayanları istedikleri anlaşılmaktadır. Genellikle özgün tasarımda sandalyeleri isteyen Z kuşağ katılımcılar, yola yakın, insanların gördükleri ve kendilerinin de insanları gördükleri bir yerde oturmayı tercih ettikleri söylenebilir. Bu tarz açı alanları tercih eden Z kuşağı katılımcıların, 
hava sıcaklığına göre havalandırma ya da ısıtıcı ekipmanların olmasını ve sigara içmeleri için ayrılmış yerlerin olmasını istedikleri anlaşılmaktadır. Z kuşağı katılımcılar, ortamın kasvetli olmamasını, eski tarz dekor ürünlerin yerine daha canlı renkleri olan ürünlerinin bulunmasını, sipariş verirken teknolojik ekipmanlardan yararlanılmasını, siparişin hazırlık ve yapım aşamaların görebilmeyi istedikleri ifade edilebilir.

Masalar ve sandalyelerin rahat olmasını beklerim. Bazı yerlerde sırt desteği bile olmayan tabure tarzı sandalyeler var kahve mi içeceğiz? Oturacak mıyız? Diye kendi kendine soruyor insan. Masaların çok yakın olması bazen rahatsiz edici olabiliyor. Bazı yerlerin havalandırma ya da klimaları yetersiz kahıyor bu yerlerin havalandırmalarının daha iyi olması gerekir (K1). Gittiğim yere göre farklı masa ve sandalyeler oluyor. Örneğin; akşam gideceksem genelde rahat sandalyeleri olan bir yeri tercih ederim. Ama sabah ya da öğle gibi genelde kısıtlı zamanım olduğunda daha ergonomik ve kısa sürede siparişlerimi yiyipiçebileceğim bir yer tercih ederim. Bazen sirf sandalye ve masası için tercih ettiğim yerler oluyor (K2). Bistro ya da tahtadan yapılmış sıkışık, dar sandalye ve masaları sevmiyorum. Bunlarda hem oturmak hem de içeceklerinizi sabit tutmak çok zor oluyor. Bir diğeri ise müzik sesi. Bazı yerlerde müziğin sesini çok açıyorlar. Orta ya da az, tadında bırakılmalı. Yazın genelde klimalı kışın ise ısısı ayarlanmış yerlere gitmeyi tercih ederim (K3). Masaların boyu çok küçük olmamalı. Sandalyeler rahat olmalı. Kışın iyice ısınmış yazın da klimalı bir yer olmalı. Bir de konuşurken ne yakınmızdakiler bizi duysun ne de biz onları. Masaların birbirine mesafesinin olması gerekir (K4).

Otururken rahatsız etmeyen sandalye ve masa tercih ederim. Masa ve sandalyenin yüksekliği iyi ayarlanmış olursa hem kahve içerken dökülme ya da masanın sallanma durumu olmaz hem de kahveye uzanmak için çaba sarf etmek zorunda kalmam. Ortam sicaklı̆̆ıın uygun olması gerekir. Sıcak kahve içerken bir de ortam çok sıcak olursa bunalmak istemem. Ortamda modern tarzda dekorlarm olmasinı isterim (K5). Bazen ders çalışıyorum bu gibi durumlarda masanın küçük ya da bistro olmasını istemem. Yakın arkadaşlarımla gidince belki bu durum sorun olmaz ama tahta ve rahatsız edici sandalyeler ya da taburelerde oturmak istemem. Masaların birbirine çok yakın olması hoşuma gitmiyor (K6). Rahat ve yumuşak sandalyede oturmak isterim. Masanın ölçüsünün iyi ayarlanmış olması gerekir. Modern yapıda olması göze daha güzel geliyor. Sigara içenler için açık alanda, servisin yapıldı̆̆ı yazın soğutuculu kışın ise isitıcıl bir yer güzel olur. (K7). Otururken rahatsız etmeyen sandalyeler ve masalar olmalı. Öğlen ve akşamüstü güneşin vurduğu bir yer olmasım istemem. Sigara içmek için ayrı bir yerde servisin de yapılması gerekir. Bazı yerlerde sigara içme yerleri var ama buraya servis yapılmıyor. Klima, havalandırma, ısıtıcı gibi aletlerle yazın soğuk kışın ise sıcak bir yer olması să̆lanması gerekir (K8). Sandalyeler ve masalar düzenli olmalı. Çok ayakaltı yerde ya da tuvalet yanında masa olmamall. Aydınlık olmalı. Masada hem kahvemi koyacak hem de yanında kek vb. kolaylıkla yiyebileceğim kadar yer olmalı. Geniş sehpa tarzında bir masa varsa bunun yüksekliğinin iyi ayarlanmış olması gerekir (K9).

Masaların manzaranın ya da ışığın güzel olduğu yerlerde olmasını isterim. Bazı yerlerde masalar kaldırıma ya da yürüyüş yoluna yakın oluyor bu yerleri tercih ederim. Masa ve sandalyelerin şeklinin ve yapısının standart masalardan farklı olması güzel oluyor. Genelde açık alanda pervane vb. ile soğutulan ya da kışın açık alanda taşıma isiticilarla isittlan yerleri de tercih ederim (K10). Rahatsız edici olmayan sandalye ve masaları tercih ederim. Ama çok kasvetli ve ağır bir ortamı da tercih etmem. Sigara içme yerinin olmasını isterim (K11). Ortamdaki dekorlarn bu lamba olabilir, vazo olabilir ya da tablo olabilir antik, rüstik ya da eski moda olmasını istemem. Özellikle sipariş verirken kahve dükkanındaki bir ekranda bunların adlarının, fotoğraflarının vb. olmasın isterim. Hem ne içtiğimi bilirim hem de ödeyeceğim ücreti. Bunlar olmasa bile en azından sosyal medya hesabı olmalı o yerin. Sosyal medyadan ücreti ya da içecekleri görmek isterim (K12). Kahve makinelerinin görünür bir yerde olması güzel oluyor. Hem yapılırken izleyebiliyorum hem de siparişimi takip edebiliyorum. Masa ve sandalyeler duruma göre bistro ya da farklı şekillerde olabilir. Yorulup geldiğimiz bir yer değil sonuçta. Illla ki dinlenmek için gelmediğimden uyku getirici bir sandalyede de oturmak istemem. Ortam çok loş ya da karanlık olmamalı, eski tarzda tablolardan daha çok canlı renkler görmek isterim (K13). 


\section{Katılımcıların Kahve Dükkanlarında Satın Aldıkları Ürünlere İlişkin Bulgular}

Katılımcıların kahve dükkanlarında satın aldıkları ürünlere ilişkin bulgulara bakıldığında $X$ kuşağı katılımcların genellikle filtre kahve, Türk kahvesi ve espresso gibi temel kahveleri tercih ettikleri görülmektedir. Ayrıca X kuşağı katılımcıların çayı da tercih ettikleri, ancak bu temel kahveler ve çay dışında farklı kahveleri deneyimlemek istemedikleri anlaşılmaktadır.

Y kuşağı katılımcıların satın aldıkları ürünlere bakıldığında, Türk kahvesi, filtre kahve ve espresso ile birlikte çay, bitki çayı, sahlep, sıcak çikolata ve cappuccino, americano da tercih ettikleri görülmektedir. Aynı zamanda Cold brew, V60, sifon ya da chemex gibi yenilikçi yöntemlerin de tercih edildiği görülmektedir. Y kuşağı katılımcıların kremalı, şuruplu ve farklı ürünlerle tadı geliştirilmiş kahveleri fazla tercih etmedikleri anlaşılmaktadır. Y kuşağı katılımcların kahvenin kalitesine, usulüne uygun pişirilmesine ya da demlenmesine dikkat ettikleri görülmektedir. Özellikle ürünün hazırlama ve sunumunda kullanılan ekipmanların kalitesi ve aslına uygun olmasının Y kuşağı katılımcılar için önemli olduğu ifade edilebilir. Yazın genellikle limonata gibi soğuk içecekleri tercih eden bu kuşak katılımcıların, içeceklerinin tümünde kaliteye, lezzete, hijyenik olmasına ve sunuma dikkat ettikleri anlaşılmaktadır.

Z kuşağı katılımcıların genellikle farklı ürünlerle karıştırılarak yapılan kahveleri tercih ettikleri söylenebilir. Özellikle krema, şurup ve çikolata ile tatlandırılan kahveleri tercih eden Z kuşağ katılımcıların, yazın sıcak soğuk kışın ise sıcak kahveleri tükettikleri anlaşılmaktadır. Mocha, latte, frappaccino ve macchiato, Z kuşağı katılımcıların aldıkları kahve çeşitlerinde öne çımaktadır. Kahvelerinin yanında kek ya da pasta almak istediklerin menü olarak kahve + tatlı şeklinde sipariş ettikleri söylenebilir. Ayrıca yazın frozen gibi soğuk meyveli içecekleri ve dondurmayı tercih ettikleri de anlaşılmaktadır.

Türk kahvesini tercih ediyorum. Bazen değişik aromalarda Türk kahveleri oluyor, damla sakızl, menengiç gibi bunlardan da içiyorum. Onun haricinde farklı kahveleri çok içmiyorum ama çay da içiyorum (K1). Genellikle filtre kahve ya da espresso içerim. O yüzden sade kahveleri tercih ediyorum (K2). Filtre kahve ya da espresso tercih ediyorum. Filtre kahveyi süt ile içmeyi seviyorum. Hafif bir şeyler içmek istersem de cappuccino ya da aromal Türk kahvesi içerim (K3). Şekerli Türk kahvesi ya da sütlü filtre kahve içerim. Bazen kahvenin yanına kek benzeri tatl bir şeyler de alıyorum. Kahvenin fazlası çarpıntı yapıyor çay da içiyorum (K4).

Kahvenin kendine özgü kokusu ve tadı benim için önemli. Filtre, espresso, americano ya da Türk kahvesini tercih ediyorum. Bazı yerlerde filtre, bazı yerlerde espresso ve bazı yerlerde de Türk kahvesi ve aromalı Türk kahvesi iyi oluyor. Tercihim nerede hangisi bana daha iyi geliyorsa onu almak oluyor. Çay ya da bitki çayı da arada içiyorum. Farklı demleme yöntemlerini denemeyi de severim. Chemex, ve sifon tarzı yöntemlerle yapılan kahveleri de içiyorum (K5). Uzun süre içebileceğim kahveleri alıyorum. Bunlar genellikle filtre kahveler oluyor. Tabii ki Türk kahvesi ya da espresso da güzel kahveler ancak porsiyonları küçük oldukları için filtre kahveyi bazen de cappuccinoyu alıyorum. Kahvenin kokusu ve yoğunluğu çok önemli. Bazı yerlerde filtre kahve olarak french presste yapilan kahve geliyor bunlarn uygun bulmuyorum. Basite kaçılmış gibi geliyor. Hem kahvede bulanık bir görüntü oluyor hem de kahvenin içine az da olsa pressleme yaparken taneleri kaçıyor. Genellikle yazın cold brewi tercih ediyorum (K6). Cappuccinoyu genellikle içiyorum. Filtre kahve ya da americano da içiyorum. Kışın kış çaylarım tercih ediyorum genellikle. Bazen sıcak çikolata ya da salep de içerim. Aslında önemli olan kaliteli yapılıp yapılmadı̆̆ı. Bu içecekleri denedikten sonra, mekandaki içecek kalitesi hakkında fikir sahibi oluyorum. Ona göre farkl yerlerin farklı ürünleri daha lezzetli ve kaliteli olabilyor. Bazı yerlerde kremal, aromalı, şuruplu kahveler yapılıyor ancak bunların kahvenin asıl tadını baskıladığını düşünüyorum. Sifon, V60, cold brew gibi farklı kahve yapma yöntemlerini de deniyorum. (K7). Filtre, espresso ya da Türk kahvesini içmeyi tercih ediyorum. Burada da önemli olan nasıl yapıldığg. Mesela hazır makinede Türk kahvesi yapan yerler var. Bu yerler bir de Türk kahvesini menüde ön plana çıkarıyorlar. Bence doğru değil. Ben kaliteli ve lezzetli Türk kahvesini bakır 
cezvede ve köz üzerinde tercih ederim. Bazen de farklı aromada Türk kahvesi içerim. Yazın limonata gibi soğuk içecekleri tercih ederim. (K8). Hijyenik, kaliteli ve lezzetli kahve içmek isterim. Tadının ve lezzetinin iyi olduğu kadar sunumunun da güzel olması gerekir. Özellikle Çin mal fincanda Türk kahvesi içmem, bu yerleri uyarırım. Türk kahvesi Türk malı fincanda içilmeli. Damla sakızl, menengiç ya da findik aromalı Türk kahvelerinde aromanın oranı da çok önemli. Filtre kahve içiyorsam doğru düzgün bir demleme yapılmalı. Çay içiyorsam tavşan kan dediğimiz, kırmızı ve berrak olmall. Salep ya da sıcak çikolata içiyorsam toz hazır ürünlerle yapılmamah aslına uygun kalitede olmalı. Yazın limonata içiyorsam bu da aslina uygun katkısız olmalıdır (K9).

Yeni kahve çeşitlerini denemeyi seviyorum. Bazı markalarda belirli dönemlerde değişik aromalar ve tatlar oluyor. Bunlar başka zamanlarda yapmıyorlar özellikle bu dönemlere ait içecekleri deniyorum. Yazın frappaccino gibi soğuk kahveleri, kışın ise sıcak kahve ve çikolata karışımı olan mocha tarzı kahveleri tercih ediyorum. Genelde farklı tatları denemeyi seviyorum. Bazen kek, pasta gibi yiyeceklerle menü şeklinde olan kahveleri de alyyorum (K10). Mocha ve latteyi tercih ediyorum. Bazen kek ve pastalar oluyor onlar da güzel oluyor. Yazın soğuk aromalı ve şuruplu soğuk kahveleri seviyorum. Kışın sıcak ve çikolata ya da findık şurubu olan kremalı kahveleri seviyorum (K11). Yazın frozen, soğuk kahveler ya da gittiğim yerde farklı dondurma çeşitleri varsa bunları deniyorum. Kışın ise sıcak aromalı, findıkll, çikolatalı gibi kahve çeşitlerini içiyorum (K12). Kahveyi sade çok sevmiyorum. Acı geliyor tadı. O yüzden krema, çikolata, findık gibi karışım kahveleri seviyorum. Yazın frozen, frappaccino gibi soğuk kahve ve meyveli içecekleri, kışın macchiato, mocha gibi sıcak kahveleri tercih ediyorum. Kahveyle tath menüleri oluyor bunlar da arada alıyorum. Farklı kahveler gördüğümde, bunları denemek de güzel oluyor (K13).

Elde edilen bulgular ile kahve tüketiminin kalite algısı ve markaya göre tercih edildiği, sosyalleşme amacıyla daha çok kahve dükkanlarının ziyaret edildiği, kahve çeşitleri konusunda $X, Y$ ve $Z$ kuşağının farklı tercih ve alışkanlıklarının bulunduğunu ortaya koymaktadır. $X, Y$ ve $\mathrm{Z}$ kuşaklarının gelenekselden farklılaşmaya giden tüketici tercihlerinin olması, kahve dükkanlarının müşteri memnuniyetini sağlama konusunda bu tercih ve beklentilere yönelik ürün ve hizmetlerin geliştirilmesi gerekliliğini ortaya koymaktadır.

\section{SONUÇ}

Günümüz tüketim toplumunda tüketicilerin satın alma davranışları ve tercih etme nedenleri araştırılırken onların temsil ettikleri kuşaklar üzerinden bunu anlamak son derece önemli olmaktadır (Ekşi, 2017). Tüketicilerin farklı değer ve düşünce yapılarına sahip olmaları nedeniyle kuşaklar dikkate alınarak tüketici profilleri ortaya çıkarılmaktadır. Özellikle kahve dükkanları gibi hizmet sektöründe yer alan işletmelerin müşteri profilinin belirlenmesi son derece önemli olmaktadır. Bu çalışmanın amacı kahve dükkanlarını tercih eden tüketicilerin tercih etme alışkanlıklarının kuşaklara göre incelenmesidir.

Çalışmanın amacı doğrultusunda elde edilen bulgular sonucunda $X$ kuşağının kahve dükkanlarına diğer kuşaklara göre daha az gittiği ve genellikle kahve dükkanlarında aileleri ile birlikte vakit geçirdikleri tespit edilmiştir. Benzer şekilde Kelgökmen ve Yalçın (2017) çalışmasında $X$ kuşağının aileleriyle daha fazla zaman ayırmaya çaba sarf ettiklerini belirtmektedir. X kuşağı, kahve dükkanı markası olarak genellikle yerli kahve dükkanlarını tercih etmektedir. Kahve dükkanlarında hizmet kalitesine dikkat eden bu kuşak ayrıca kahve dükkanlarında bilindik lezzetleri tercih etmektedirler.

Kahve dükkanlarını tercih eden $\mathrm{Y}$ kuşağı tüketicileri genellikle yoğun iş temposundan uzaklaşmak için yerli veya yabancı kahve dükkanlarını tercih etmektedir. Hizmet kalitesine ve fiziki unsurlara dikkat eden bu kuşak aynı zamanda gittikleri kahve dükkanlarında kahvenin kalitesine, demleme yöntemine dikkat ettikleri saptanmıştır. Yazıcı (2018) çalışmasında benzer 
şekilde $Y$ kuşağ tüketicileri için ürün ve hizmette kalitenin en önemli etken olduğunu ifade etmiştir. Aynı zamanda kahve dükkanlarında cold brew, V60, sifon ya da chemex gibi yeni nesil kahve demleme yöntemleri tercih etmektedirler. Y kuşağı kahve dükkanlarının genellikle modern görünüme sahip olmasını istemektedir. Dedeoğlu vd., (2019) tüketicilerin kuşak farklılıkları ve fiziki hizmet alanı algılamalarını inceledikleri çalışmada benzer şekilde $\mathrm{Y}$ kuşağının mekanlarda ki modern algilamaların diğer kuşaklara göre daha fazla olduğunu belirtmektedir.

Farklı kahve deneyimlerine açık olan Z kuşağı kahve dükkanlarına genellikle arkadaşlarıyla birlikte gitmektedirler. Bu kuşak tüketicileri marka kahve dükkanları tercih ettiği gibi farklı kahve deneyimlerine açık olduğu için butik kahve dükkanlarını da tercih etmektedirler. Y kuşağ 1 gibi yeni nesil demleme yöntemlerini de tercih etmektedirler. Self servis hizmetini genellikle tercih eden bu kuşak tüketicileri ayrıca sosyal medyayı aktif bir şekilde kullandıkları için gittikleri kahve dükkanlarında internet erişimine ve çeşitli teknolojik hizmetlere önem vermektedirler. Sarı ve Harta (2018) da benzer şekilde çalışmasında interneti en çok Z kuşağının kullandığını ifade etmiştir.

X, Y, Z kuşakların özellikleri dikkate alınarak gerçekleştirilen pazarlama faaliyetleri günümüzde giderek daha önemli hale gelmektedir. Kuşakların dikkate alınmasıyla tüketicilerin kahve dükkanlarını tercih etme alışkanlıklarının incelendiği bu çalışma uygulamada kahve dükkanı yöneticilerine önemli katkılar sağlayabilecek niteliktedir. Kahve dükkanlarının pazarlama süreçlerini kuşakları dikkate alarak planlamaları rekabet ortamında başarılı olmaları için büyük önem taşımaktadır. Y kuşağının kaliteli ortam ve kaliteli kahve beklentisi ile teknolojik gelişmeleri takip eden ve sosyal medyaya ilgili $Z$ kuşağına yönelik geliştirmelerin yapılması, sosyal medyada kahve ve kahve çeşitlerine ilişkin etkinliklere ağırlık verilmesi kahve dükkanları açısından rekabet avantajı yaratacağından kahve dükkanı işletmelerine katkı sağlayacağı ifade edilebilir. Kahve dükkanlarının atmosfer ve konforunun $\mathrm{Z}$ kuşağının daha çok rahat edebileceği bir şekilde düzenlenmesi önerilebilir.

Çalışmanın konusu üzerine daha önce bir araştırma yapılmamış olması nedeniyle ilgili literatüre de katkı sağlayacağı düşünülmektedir. Bundan sonra yapılacak olan çalışmalarda kahve dükkanlarının pazarlama faaliyetlerine ilişkin $X, Y$ ve $Z$ kuşaklarının etkisine yönelik çalışmalar yapilması planlanabilir.

$\mathrm{Bu}$ çalışmanın birtakım sınırlılıkları da bulunmaktadır. Çalışmada nitel araştırma yöntemlerinden görüşme tekniği tercih edilmiştir. Başka çalışmalarda farklı araştırma yöntem ve tekniklerin kullanılması ilgili literatüre daha fazla katkı sağlayacağı ifade edilebilir. Bu çalışma Antalya il merkezinde $X, Y$ ve $Z$ kuşağ çerçevesinde yapılmış olması sebebiyle çalışmanın genellemesi mümkün olmamaktadır. Çalışmanın bulguları ve sonucu katılımcılarla yapılan görüşmelerle sınırlı kalmaktadır. Bu bağlamda ileride yapılacak olan çalışmalar farklı örneklem üzerinde farklı araştırma yöntemleri ile daha detaylı ve kapsamlı bir şekilde gerçekleştirilebilir.

\section{KAYNAKÇA}

Albayrak, A., ve Özkul, E. (2013). Y Kuşağı Turistlerin Destinasyon İmaj Algıları Üzerine Bir Araştırma. Electronic Turkish Studies, 8(6): 15-31.

Altuntuğ, N. (2012). Kuşaktan kuşağa tüketim olgusu ve geleceğin tüketici profili. Organizasyon ve Yönetim Bilimleri Dergisi, 4(1): 203-212. 
Aşık, N. A. (2017). Değişen Kahve Tüketim Alışkanlıkları ve Türk Kahvesi Üzerine Bir Araştırma. Journal of Tourism and Gastronomy Studies, 5(4): 310- 325.

Başgöze, P., ve Bayar, N. A. (2015). Eko Otellerden Hizmet Satın Alımında Kuşaklar Arası Farklılaşmalar Üzerine Bir Çalışma. Sosyoekonomi, 23(2): 118-130.

Bayrakdaroğlu, F., ve Özbek, Ç. (2018). Kadınların Tüketim Alışkanlıklarının Kuşaklararası Boyutu. Muğla Sttkı Koçman Üniversitesi. Journal of Social Sciences, 19(42): 1-12.

Berkup, S.B. (2014). Working with Generations $X$ and $Y$ in Generation Z Period: Management of Different Generations In Business Life. Mediterranean Journal of Social Sciences, 5(19): 218-229.

Bezgin, L. (2016). X, Y, Z Kuşağı Tüketicilerinin Yeniden Satın Alma Kararı Üzerinde Algılanan Marka Denkliği Öğglerinin Etki Düzeyi Farklliklarının Nörogörüntüleme Tekniklerinden Elektroensefalografi (EEG) ve Göz İzleme Yöntemleriyle Belirlenmesine Dair Deneysel Bir Çalışma. Yayımlanmamış Yüksek Lisan Tezi, Hitit Üniversitesi Sosyal Bilimler Enstitüsü.

Chadios, K. (2005). The urban coffee shop, Yayınlanmış Yüksek Lisans Tezi, Massachusetts Instıtute of Technology, Massachusetts.

Creswell, J. W. (2018). Nitel Araştırma Yöntemleri Beş Yaklaşıma Göre Nitel Araştırma ve Araştırma Deseni. (Çevirenler, Bütün, M. ve Demir, S. B.), Ankara: Siyasal Kitabevi.

Çetin, C., ve Karalar, S. 2016. X, Y ve Z Kuşağı Öğrencilerin Çok Yönlü ve Sınırsız Kariyer Algıları Üzerine Bir Araştırma, Yönetim Bilimleri Dergisi, 14(28): 157-197.

Dedeoğlu, B. B., Çalışkan, C., ve Boğan, E. (2019). Tüketicilerin Kuşak Farklılıkları ve Fiziki Hizmet Alanı Algılamaları: Otel İşletmeleri Üzerine Bir Araştırma. Gastroia: Journal of Gastronomy and Travel Research, 3(4): 776-787.

Ekşi, N. (2017). Yeni Ürün Geliştirme Sürecinde X-Y-Z Kuşaklarının Satın Alma Tercihlerindeki Farklllıkların ve İlişkilerin İncelenmesi: Cep Telefonu Üzerine Uygulama, Yayınlanmamış Yüksek Lisans Tezi, Karadeniz Teknik Üniversitesi, Trabzon.

Gülez, N. (2014), Üç Kuşak Kadın Tüketicilerin Lüks Marka Taklitlerini Satın Alma Tutumları, Yayınlanmamış Yüksek Lisans Tezi, Abant İzzet Baysal Üniversitesi, Bolu.

Gümüş, N. (2019). Z Kuşağı Tüketicilerin Satın Alma Karar Tarzlarının İncelenmesi. Journal of Yaşar University, 15(58), 381-396.

Ilgaz, M. (2018). Kuşaklar Arası Hedonik Tüketim Davranışlarının Demografik Özelliklere Göre Farklılıkları: Kastamonu İli Merkez İlçesi Üzerine Bir Araştırma. Turkish Journal of Marketing, 3(1), $1-17$.

İnce, E. (2018). Türkiye'de Popüler Kültürle Değişen Kahve Kültürü, Yayımlanmamış Yüksek Lisans Tezi, Üsküdar Üniversitesi, İstanbul.

İzmirlioğlu, K. (2008). Konumlandırmada Kuşak Analizi Yardımıyla Tüketici Alg̨larımın Tespiti: Türk Otomotiv Sektöründe Bir Uygulama, Yayınlanmamış Yüksek Lisans Tezi, Muğla Üniversitesi, Muğla.

Kelgökmen İ. D., ve Yalçın, B. (2017). Y Jenerasyonunun Farklılaşan İş Değerleri ve Liderlik Alg1lamalar1. Journal of Yasar University, 12(46): 136-160.

Kotler, P. (2000). Pazarlama Yönetimi, Millennium Baskı. (Çeviren, Muallimoğlu, N.) İstanbul, Beta Yayıncilik.

Lancaster, L. C., and Stillman, D. (2003). When generations collide: Who they are, why they clash, how to solve the generational puzzle at work. New York, NY: Harper Business. 
Levickaité, R. (2010). Generations X, Y, Z: How Social Networks Form the Concept of the World Without Borders (The Case of Lithuania), LIMES, 3 (2), 170-183.

Manzo, J. (2014). Machines, People, and Social Interaction in "Third-Wave" Coffeehouses. Journal of Arts and Humanities, 3(8), 1-12.

Parker, R. S., Hermans, C. M., and Schaefer, A. D., (2004). Fashion Consciousness of Chinese, Japanese and American Teenagers. Journal of Fashion Marketing and Management. 8(2), 176-86.

Sarı, E., ve Harta, G. (2018). Kuşakların Tüketim ve Satın Alma Davranışları Üzerine Bir Araştırma. Journal of International Social Research, 11(61): 967-980.

Sarıoğlu, E. B. ve Özgen, E. (2018). Z Kuşağının Sosyal Medya Kullanım Alışkanlıkları Üzerine Bir Çalışma. Uluslararası Sosyal Araştırmalar Dergisi, 11 (60): 1068-1081.

Schmidt, I., Ouyang, F., and Zhu, Y. (2012). Coffee Shop Culture: An Observational Study. Komuniti, 4(12): 1-11.

Trower, C. A. (2009). Traditionalists, Boomers, Xers, And Millennials; Giving and Getting the Mentoring You Want. Brown University Mentoring Luncheon, October, 16.

Tuncer, A. İ. ve Tuncer, M. U. (2016). Eğlence Reklamlarının Viral Uygulamaları ve Z Kuşağı Üzerinden Bir Değerlendirme. TRT Akademi, 1 (1) 211-229.

Twenge, J. M., Campbell, S. M., Hoffman, B. J., and Lance, C. E. (2010). Generational differences in work values: Leisure and extrinsic values increasing, social and intrinsic values decreasing. Journal of Management, 36(5), 1117-1142.

Ünver, A. (2019). Y ve Z Kuşă̆ının Hedonik ve Faydacı Tüketim Davranışlarının Marka Sadakatine Etkisinin İncelenmesi. Yayınlanmamış Yüksek Lisans Tezi, Bartın Üniversitesi, Bartın.

Williams, K. C., and Page, R. A. (2011). Marketing to the generations. Journal of Behavioral Studies in Business, 3(3), 1-17.

Yazıcı, B. (2018). Yeni Lüks Kavramı Bağlamında Y Kuşağı ile Evrilen Tüketim ve Y Kuşağının Lüks Kavramına Bakışı. Kocaeli Üniversitesi Sosyal Bilimler Dergisi, (36), 95-112.

Yıldırım, A., ve Şimşek, H. (2018). Sosyal Bilimlerde Nitel Araştırma Yöntemleri, Ankara: Seçkin Yayıncilik. 